\title{
Fixation and Recovery of Added Phosphorus and Potassium in Different Soil Types of Pulse-Growing Regions of India
}

\author{
C. Srinivasarao \\ International Crops Research Institute for Semiarid Tropics, Patancheru, \\ Andhra Pradesh, India
}
R. N. Singh, A. N. Ganeshamurthy, Ghansham Singh, and Masood Ali
Division of Crop Production, Indian Institute of Pulses Research, Kanpur,
Uttar Pradesh, India

\begin{abstract}
Fixation and recovery of added phosphorus $(\mathrm{P})$ and potassium $(\mathrm{K})$ were studied in different soil types of pulse-growing regions. Amounts of $\mathrm{P}$ and $\mathrm{K}$ fixed increased in all the soils irrespective of type and texture. With the increase in levels of added $\mathrm{P}$ and $\mathrm{K}$, maximum $\mathrm{P}$ fixation was observed at lower levels of added $\mathrm{P}$ $\left(50 \mathrm{mg} \mathrm{kg}^{-1}\right)$. Alfisols showed maximum P-fixation capacity $(92.7 \%)$, followed by Vertisols $(86.5 \%)$ and Inceptisols $(76.6 \%)$ at $50 \mathrm{mg} \mathrm{kg}^{-1}$ added P. However, $\mathrm{K}$ fixation increased with increasing levels of added $\mathrm{K}$ up to $200 \mathrm{mg} \mathrm{kg}^{-1}$, and thereafter fixation either decreased or was maintained at similar levels. Vertisols showed higher $\mathrm{K}$ fixation than Inceptisols and Alfisols. Fertilizer P requirement per unit increase in available P in soil was highest in Bangalore (3.23) and lowest in Delhi (2.38). Fertilizer $\mathrm{K}$ requirement per unit increase in available $\mathrm{K}$ in soil was highest in Raipur and Gulbarga (1.75) and lowest in Ranchi (1.28).
\end{abstract}

Keywords: Fixation, recovery, $\mathrm{P}$ and $\mathrm{K}$, pulse growing regions, soil types

Received 23 February 2004, Accepted 18 April 2005

Address correspondence to C. Srinivasarao, International Crops Research Institute for Semiarid Tropics, Patancheru, 502324 Andhra Pradesh, India. E-mail: cheruku65@rediffmail.com 


\section{INTRODUCTION}

Most of the added nutrients to soils, particularly phosphorus $(\mathrm{P})$ and potassium $(\mathrm{K})$, are fixed in soil in temporarily plant-unavailable forms (Kanwar, Goswami, and Kamath 1982). The type and extent of these fixation reactions in soil are influenced by a number of factors such as soil $\mathrm{pH}$, type and amount of clay, and chemical composition of soil (Shaviv et al. 1985). India is the world's largest grower of pulse crops (food legumes) covering about 23.0 million hectares and producing about 14.8 million tons. Pulses are mostly grown under rain-fed conditions on marginal and submarginal lands, covering different types of soils. Additions of $\mathrm{P}$ to various pulse crops are recommended at the rates of 40 to $80 \mathrm{~kg} \mathrm{P}_{2} \mathrm{O}_{5} \mathrm{ha}^{-1}$ and $\mathrm{K}$ at 20 to $40 \mathrm{~kg} \mathrm{~K}_{2} \mathrm{O} \mathrm{ha}^{-1}$. Fixation studies provide information on the reaction rates and fate of the added $\mathrm{P}$ and $\mathrm{K}$, thereby helping to formulate strategies for better management of $\mathrm{P}$ and $\mathrm{K}$ and compute optimum $\mathrm{P}$ and $\mathrm{K}$ requirements of these pulse crops. The present study examines the fixation of added $\mathrm{P}$ and $\mathrm{K}$ and the recovery in different soil types of pulse-growing regions of India.

\section{MATERIALS AND METHODS}

\section{Soils}

Soil samples (15-cm interval) were collected from 10 locations: four Inceptisols (Kanpur, Faizabad, Delhi, and Varanasi), three Vertisols (Sehore, Raipur, and Gulbarga), and three Alfisols (Hyderabad, Ranchi, and Bangalore) covering seven states and major soil groups. The soil samples were processed and analyzed for different chemical properties (Jackson 1973). Total iron $(\mathrm{Fe})$ and aluminum $(\mathrm{Al})$ were determined by following procedures outlined in Jackson (1973) after digesting the soil by microwave digestion system (model MLS 1200) (Table 1).

\section{Phosphorus-Fixation Capacity}

Two grams of surface soil samples $(<2 \mathrm{~mm})$ were equilibrated with $20 \mathrm{~mL}$ of $0.01 \mathrm{M}$ calcium chloride $\left(\mathrm{CaCl}_{2}\right)$ solution containing graded levels of calcium phosphate $\left[\mathrm{Ca}\left(\mathrm{H}_{2} \mathrm{PO}_{4}\right)_{2} \cdot \mathrm{H}_{2} \mathrm{O}\right]$. The $\mathrm{P}$ levels used were $0,50,100,200,400$, 800 , and $1600 \mathrm{mg} \mathrm{kg}^{-1}$. Two drops of toluene were added to each flask and incubated for $96 \mathrm{~h}$ at room temperature $\left(25^{\circ} \mathrm{C}\right)$ (Waugh and Fitts 1966). After incubation, $P$ was extracted by Olsen's reagent (Olsen et al. 1954) for neutral and alkaline soils and by Bray's one reagent (Bray and Kurtz 1945) for acidic soils. The $\mathrm{P}$ concentration in the soil extracts was determined in the aliquot colorimetrically. Fixed $\mathrm{P}$ was computed by the difference between the initial and the equilibrium P concentrations (Fox and Kamprath 1970). 
Table 1. Locations and properties of soils 


\section{Potassium-Fixation Capacity}

Two grams each of surface soil samples $(<2 \mathrm{~mm})$ were incubated with $2 \mathrm{~mL}$ of $\mathrm{K}$ solution varying in levels for $72 \mathrm{~h}$ at room temperature (Verma and Verma 1970). The $\mathrm{K}$ levels used were 0, 50, 100, 200, 400, and $800 \mathrm{mg} \mathrm{K} \mathrm{kg}{ }^{-1}$. After incubation, $8 \mathrm{ml}$ of $1 \mathrm{~N}$ ammonium acetate solution was added and shaken for 5 min (Hanway and Heidel 1952). Potassium was estimated by flame photometer. Fixed $\mathrm{K}$ was computed using the formula

$$
\begin{aligned}
\mathrm{K} \text { fixed }= & \mathrm{K} \text { applied }-(\text { Extractable } \mathrm{K} \text { in treated soil } \\
& - \text { extractable } \mathrm{K} \text { in control }) .
\end{aligned}
$$

\section{RESULTS AND DISCUSSION}

\section{Soil Properties}

All the soils were low in organic carbon $(<0.50 \%)$ despite long-term pulse cultivation on these soils (Table 1). Soils from Hyderabad, Ranchi, and Bangalore were acidic, and the rest of the soils were alkaline in reaction. Electrical conductivity was normal in all the soils except in that from Faizabad, where a slightly higher EC was observed. Black soils from Sehore, Raipur, and Gulbarga were calcareous, and the rest were noncalcareous in nature. The Vertisols were clay in texture, Alfisols were sandy clay loam, and Inceptisols were loam to silty loam. The total $\mathrm{Fe}$ and $\mathrm{Al}$ oxide (sesquioxide) content ranged from 15.5 to $24.0 \%$ in Inceptisols, 25.9 to $42.2 \%$ in Vertisols, and from 24.4 to $48.6 \%$ in Alfisols.

\section{Phosphorus Fixation}

Amount of $\mathrm{P}$ fixed in the different soils with $\mathrm{P}$ levels increasing from 50 to $1600 \mathrm{mg} \mathrm{kg}^{-1}$ (Table 2) showed that at all the levels of added P, Alfisols fixed greater amounts of $\mathrm{P}$ followed by Vertisols, and then Inceptisols. The highest percent of $\mathrm{P}$ fixation occurred at lower levels of added $\mathrm{P}$ $\left(50 \mathrm{~m} \mathrm{~kg}^{-1}\right)$ in all the soils, and it gradually decreased with increasing $\mathrm{P}$ levels. The mean percent $\mathrm{P}$ fixation among soil types at lower levels of added $\mathrm{P}$ is shown in Figure 1. These lower levels of $\mathrm{P}$ are the levels generally recommended for different pulse crops. At $50 \mathrm{mg} \mathrm{kg}^{-1}$ $\left(112 \mathrm{~kg} \mathrm{P} \mathrm{ha}^{-1}\right)$ the percent $\mathrm{P}$ fixation was highest in Alfisols (87) and lowest in Inceptisols (77). At $100 \mathrm{mg} \mathrm{kg}^{-1}$ of added P, similar levels of fixation were observed in different soil types, but with further increase in added $\mathrm{P}$, the percent fixation decreased. However, the amount of added $\mathrm{P}$ fixed increased with increasing levels of added P. The increase in amount 
Table 2. Phosphorus fixation characteristics of different soil types of pulse growing regions of India

\begin{tabular}{|c|c|c|c|c|c|c|c|c|c|c|c|c|}
\hline \multirow{3}{*}{$\begin{array}{l}\text { Soil type/ } \\
\text { location }\end{array}$} & \multicolumn{12}{|c|}{ Added P } \\
\hline & \multicolumn{2}{|r|}{50} & \multicolumn{2}{|r|}{100} & \multicolumn{2}{|r|}{200} & \multicolumn{2}{|r|}{400} & \multicolumn{2}{|r|}{800} & \multicolumn{2}{|c|}{1600} \\
\hline & $(\%)^{a}$ & $\left(\mathrm{mg} \mathrm{kg}^{-1}\right)^{b}$ & $(\%)$ & $\left(\mathrm{mg} \mathrm{kg}^{-1}\right)$ & $(\%)$ & $\left(\mathrm{mg} \mathrm{kg}^{-1}\right)$ & $(\%)$ & $\left(\mathrm{mg} \mathrm{kg}^{-1}\right)$ & $(\%)$ & $\left(\mathrm{mg} \mathrm{kg}^{-1}\right)$ & $(\%)$ & $\left(\mathrm{mg} \mathrm{g}^{-1}\right)$ \\
\hline \multicolumn{13}{|l|}{ Inceptisols } \\
\hline Kanpur & 82 & 41 & 81 & 81 & 79 & 158 & 72 & 286 & 65 & 520 & 62 & 986 \\
\hline Faizabad & 77 & 39 & 76 & 76 & 73 & 146 & 68 & 272 & 62 & 498 & 60 & 963 \\
\hline Delhi & 75 & 37 & 75 & 75 & 70 & 140 & 67 & 268 & 60 & 481 & 59 & 952 \\
\hline Varanasi & 76 & 38 & 75 & 75 & 70 & 140 & 67 & 268 & 61 & 491 & 60 & 958 \\
\hline \multicolumn{13}{|l|}{ Verkisols } \\
\hline Sehore & 81 & 40 & 80 & 80 & 80 & 160 & 72 & 286 & 65 & 519 & 62 & 998 \\
\hline Raipur & 85 & 43 & 88 & 87 & 88 & 174 & 75 & 299 & 68 & 541 & 66 & 1058 \\
\hline Gulbarga & 90 & 45 & 91 & 89 & 91 & 178 & 79 & 315 & 70 & 562 & 67 & 1071 \\
\hline \multicolumn{13}{|l|}{ Alfisols } \\
\hline Hyderabad & 93 & 47 & 92 & 89 & 92 & 178 & 80 & 320 & 71 & 570 & 68 & 1082 \\
\hline Ranchi & 90 & 45 & 91 & 89 & 91 & 178 & 82 & 326 & 70 & 560 & 67 & 1070 \\
\hline Bangalore & 96 & 48 & 95 & 90 & 95 & 181 & 85 & 340 & 75 & 600 & 70 & 1020 \\
\hline
\end{tabular}

${ }^{a}$ Percent of added $\mathrm{P}$ fixed.

${ }^{b}$ Amount of added P fixed. 


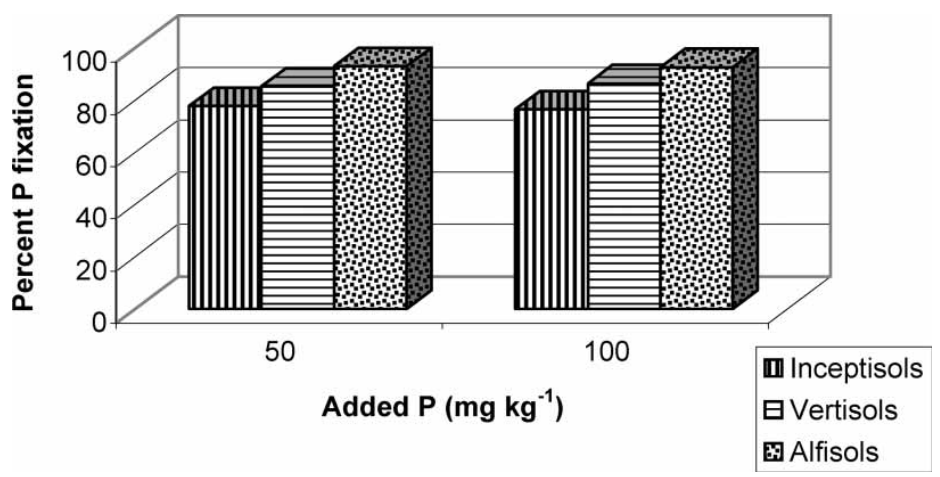

Figure 1. Percent $\mathrm{P}$ fixation at various levels of added $\mathrm{P}$ in different soil types.

of $\mathrm{P}$ fixation with the increase of added $\mathrm{P}$ might be attributed to the increase in ionic strength generated by addition of P. It has been reported that the increased ionic strength lowers the activity coefficient, which may raise the concentration of reaction products in soils per the solubility product principle (Sanyal and DeDatta 1991). The adsorbed $P$ serves as a reservoir for regeneration of solution $P$, the concentration of which influences the diffusion of phosphate to plant roots, followed by its absorption by plants (Barrow 1979).

Among Inceptisols, soils of Kanpur showed maximum P fixation of $82 \%$ followed by the soils from Faizabad (77\%), Varanasi (76\%), and Delhi (75\%) at $50 \mathrm{mg} \mathrm{kg}^{-1}$ of added P. At higher levels of added $\mathrm{P}\left(1600 \mathrm{mg} \mathrm{kg}^{-1}\right)$ the difference in percent fixation among four Inceptisols reduced considerably, ranging from 60 to 62 . Among Vertisols at $50 \mathrm{mg} \mathrm{kg}^{-1}$ of added $\mathrm{P}$, percent fixation was the highest in Gulbarga soil (90\%), followed by Raipur soil (85\%); the lowest was in Sehore soil (81\%). A similar trend was observed at the highest level of added P. Among Alfisols, with a pretreatment of $50 \mathrm{mg} \mathrm{kg}^{-1}$, Bangalore soils had the highest $\mathrm{P}$ fixation of $96 \%$ followed by soils from Hyderabad (93\%); the lowest was in Ranchi (90\%). The clay fraction in the Alfisols, predominantly containing kaolinite and accessory oxide and hydrous oxides of $\mathrm{Fe}$ and $\mathrm{Al}$, played an active role in sorption (Milap-Chand, Randhawa, and Vig 1995). In general, in each soil type, the percent $\mathrm{P}$ fixation varied according to the amount of clay content in the soil. Among Vertisols, soils of Gulbarga, with $71.6 \%$ clay, showed the maximum percent $\mathrm{P}$ fixation at all the levels of added $\mathrm{P}$ as compared to soils of Sehore (clay: 61.5\%). Relationships established between the P-fixation factor obtained from a regression equation connecting increases in available $\mathrm{P}$ with added $\mathrm{P}$ suggested that a P-fixation factor had a significant positive correlation with $\mathrm{Fe}$ oxides $\left(0.74^{*}\right)$ and nonsignificant positive relationship with $\mathrm{Al}$ oxide content in soil (0.62). However, when $\mathrm{Fe}$ and $\mathrm{Al}$ (sesquioxides) were taken together, the $r$ values improved to $0.77^{*}$ (Figure 2). The positive correlation between total oxides of $\mathrm{Fe}$ and $\mathrm{Al}$ with $\mathrm{P}$ fixation may be due to the 
formation of insoluble phosphates of $\mathrm{Fe}$ and $\mathrm{Al}$. The relationship of $\mathrm{P}$ fixation factor with $\mathrm{pH}$ was negative $\left(-0.78^{*}\right)$, which could be due to gradual dissolution of $\mathrm{Fe}$ and $\mathrm{Al}$ oxides and their subsequent precipitation as phosphates with lowering of $\mathrm{pH}$ values (Mallikarjuna et al. 2003). Clay content showed a significant relation to the $\mathrm{P}$ fixation factor in all the soil types, but the extent of correlation was much higher in Alfisols $\left(0.94^{* *}\right)$ than Vertisols $\left(0.92^{* *}\right)$ and was lowest in Inceptisols $\left(0.68^{\mathrm{NS}}\right)$. Significant correlation of phosphate sorption parameters with clay content has been reported by several workers (Tomar and Gautam 1996; Toor, Ball, and Viag 1997), and this may be a mere reflection of the effect of specific surface area (Sanyal and De-Datta 1991). Milap-Chand, Randhawa, and Vig (1995) reported that CEC and clay were the predominant determinants of phosphate sorption.

\section{Potassium Fixation}

Irrespective of soil type and clay content, amount of $\mathrm{K}$ fixed increased with increasing $\mathrm{K}$ additions ranging from $50 \mathrm{mg} \mathrm{kg}^{-1}$ to $800 \mathrm{mg} \mathrm{kg}^{-1}$ (Table 3). In general, Vertisols and Inceptisols showed higher amounts of $\mathrm{K}$ fixation than Alfisols. Most of the soils showed the highest percent $\mathrm{K}$ fixation when $\mathrm{K}$ was added between 50 to $200 \mathrm{mg} \mathrm{kg}^{-1}$, and thereafter, either similar levels or a decrease in percentage of $\mathrm{K}$ fixation was observed. However, mean percentage of $\mathrm{K}$ fixation in all the soils types increased between 50 and $100 \mathrm{mg} \mathrm{kg}^{-1}$ of added K (Figure 3). This differential K-fixation capacity of soils could be attributed to the variability in soil texture and mineralogy. In studies reporting on fixation characteristics of mineralogically different benchmark soils of India, Srinivasarao et al. (2000) indicated that smectitic Vertisols and Vertic subgroups showed greater K-fixation capacity followed by illitic

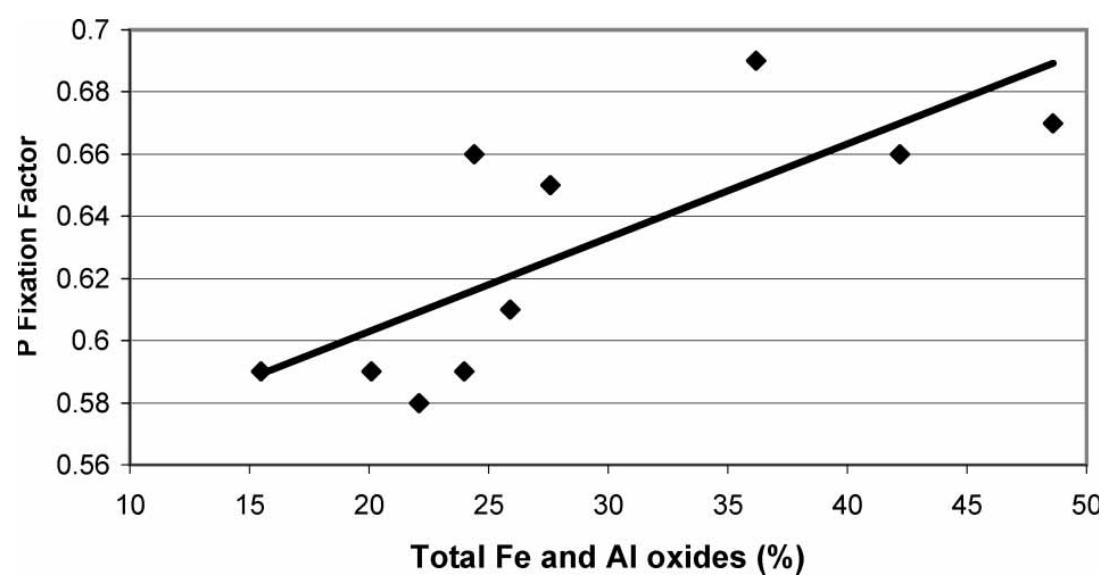

Figure 2. Relationship between total $\mathrm{Fe}$ and $\mathrm{Al}$ oxides and $\mathrm{P}-$ fixation factor in pulse growing soils. 
Table 3. Potassium fixation characteristics of different soil types of pulse growing regions of India

\begin{tabular}{|c|c|c|c|c|c|c|c|c|c|c|}
\hline \multirow{3}{*}{$\begin{array}{l}\text { Soil type/ } \\
\text { location }\end{array}$} & \multicolumn{10}{|c|}{ Added K } \\
\hline & \multicolumn{2}{|r|}{50} & \multicolumn{2}{|r|}{100} & \multicolumn{2}{|c|}{200} & \multicolumn{2}{|r|}{400} & \multicolumn{2}{|c|}{800} \\
\hline & $(\%)^{a}$ & $\left(\mathrm{mg} \mathrm{kg}^{-1}\right)^{b}$ & $(\%)$ & $\left(\mathrm{mg} \mathrm{kg}^{-1}\right)$ & $(\%)$ & $\left(\mathrm{mg} \mathrm{kg}^{-1}\right)$ & $(\%)$ & $\left(\mathrm{mg} \mathrm{kg}^{-1}\right)$ & $(\%)$ & $\left(\mathrm{mg} \mathrm{kg}^{-1}\right)$ \\
\hline \multicolumn{11}{|l|}{ Inceptisols } \\
\hline Kanpur & 30 & 15 & 42 & 42 & 41 & 82 & 41 & 162 & 41 & 324 \\
\hline Faizabad & 36 & 18 & 46 & 46 & 44 & 88 & 43 & 170 & 42 & 335 \\
\hline Delhi & 26 & 13 & 32 & 32 & 28 & 56 & 31 & 122 & 25 & 198 \\
\hline Varanasi & 34 & 17 & 45 & 45 & 43 & 86 & 43 & 170 & 42 & 332 \\
\hline \multicolumn{11}{|l|}{ Vertisols } \\
\hline Sehore & 36 & 18 & 46 & 46 & 44 & 88 & 44 & 175 & 43 & 340 \\
\hline Raipur & 40 & 20 & 42 & 42 & 40 & 80 & 45 & 175 & 42 & 336 \\
\hline Gulbarga & 48 & 24 & 49 & 49 & 47 & 94 & 46 & 180 & 44 & 348 \\
\hline \multicolumn{11}{|l|}{ Alfisols } \\
\hline Hyderabad & 24 & 12 & 28 & 28 & 30 & 59 & 30 & 118 & 23 & 184 \\
\hline Ranchi & 20 & 10 & 25 & 25 & 27 & 54 & 27 & 107 & 21 & 171 \\
\hline Bangalore & 26 & 13 & 30 & 30 & 31 & 62 & 32 & 128 & 24 & 194 \\
\hline
\end{tabular}




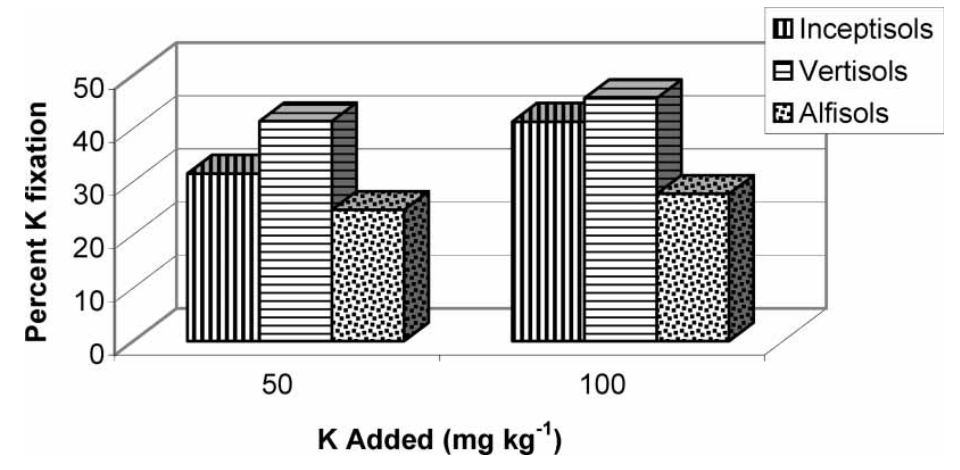

Figure 3. Percent $\mathrm{K}$ fixation at various levels of added $\mathrm{K}$ in different soil types.

and kaolinitic soils. In Inceptisols, the highest $\mathrm{K}$ fixation was observed in soils of Faizabad (46\%), followed by Varanasi (45\%), Kanpur (42\%), and Delhi $(32 \%)$. Soils with finer texture such as Faizabad $(24.6 \%)$ and Varanasi (23.5\%) showed higher K fixation compared to light-textured Delhi soils (clay: 18.0\%). Among Vertisols, the highest percentage $\mathrm{K}$ fixation was observed in soils of Gulbarga (49\%). The K fixation at higher levels of added K in Sehore soils is higher than Raipur despite its lower clay contents, which might be due to variation in associated clay minerals. Higher K fixation in Gulbarga soils could be due to larger amounts of clay content (70.6\%) compared to other soils with relatively lower clay. Relationships established between clay content and the K-fixation factor showed significant positive correlation in all the soil types: Inceptisols $\left(0.87^{*}\right)$, Vertisols $\left(0.84^{*}\right)$, and Alfisols $\left(0.99^{* *}\right)$. Srinivasarao et al. (2000) showed that the variations in K-fixation capacity among benchmark soil series were mainly due to differences in clay content in soils.

Among Alfisols, soils of Hyderabad and Bangalore showed similar levels of $\mathrm{K}$ fixation, ranging from 24 to $32 \%$, whereas in Ranchi soils $\mathrm{K}$ fixation ranged between 20 and 27\%. Lower clay contents in Ranchi soil as compared to Hyderabad and Bangalore soils might have contributed to lower levels of $\mathrm{K}$ fixation. Fixation of added $\mathrm{K}$ and its retention in a slowly available form is beneficial in light-textured sandy soils, which otherwise is leached down to deeper layers. Because many studies have established that crop $\mathrm{K}$ needs were mostly met from nonexchangeable or fixed $\mathrm{K}$ (Mengel 1985; Srinivasarao, Subba Rao, and Rupa 2001), fixing of added K in lighttextured soils would act as a reserve source of $\mathrm{K}$ in soil.

\section{Recovery of $P$ and $K$}

Recovery rates of added $\mathrm{P}$ and $\mathrm{K}$ were computed based on regression equations connecting increase in available nutrients with the amount of 
added nutrients (Table 4). Recovery of added $\mathrm{P}$ was highest in Inceptisols (0.40-0.42), followed by Vertisols (0.34-0.39); the lowest was for Alfisols (0.31-0.34). On the other hand, $\mathrm{P}$ fixation per unit of added $\mathrm{P}$ was higher in Alfisols than in Vertisols and Inceptisols. Based on recovery rate, unit of $P$ fertilizer rate required per unit increase in available $P$ in soil was calculated. Requirement of $\mathrm{P}$ in Alfisols varied from 2.94 to 3.23, Vertisols from 2.56 to 2.94, and Inceptisols from 2.38 to 2.50 units per unit increase in available P content in soils. Mean levels of required $\mathrm{P}$ units for different soil types are presented in Figure 4, indicating the highest requirement of $\mathrm{P}$ in Alfisols (3.07) as compared to Vertisols and Inceptisols.

Table 4. Recovery of $\mathrm{P}$ and $\mathrm{K}$, fixation, and unit fertilizer rate required for unit increase in available nutrient in different soil types of pulse growing regions of India

\begin{tabular}{|c|c|c|c|c|}
\hline Soil/location & $\begin{array}{c}\text { Equation connecting } \\
\text { increase in available } \mathrm{P} \\
\text { or } \mathrm{K} \text { with added } \mathrm{P} \text { or } \mathrm{K} \\
(\mathrm{X})\end{array}$ & $\begin{array}{l}\mathrm{P} \text { or } \mathrm{K} \\
\text { recovery } \\
\text { rate/unit }\end{array}$ & $\begin{array}{l}\mathrm{P} \text { or } \mathrm{K} \\
\text { fixation } \\
\text { rate/unit }\end{array}$ & $\begin{array}{c}\text { Unit fertilizer } \mathrm{P} \text { or } \\
\mathrm{K} \text { rate required per } \\
\text { unit increase in } \\
\text { available } \mathrm{P} \text { or } \mathrm{K}\end{array}$ \\
\hline \multicolumn{5}{|l|}{ Phosphorus } \\
\hline \multicolumn{5}{|l|}{ Inceptisols } \\
\hline Kanpur & $\mathrm{Y}=-2.83+0.41 \mathrm{X}$ & 0.41 & 0.59 & 2.43 \\
\hline Faizabad & $Y=-2.16+0.41 X$ & 0.41 & 0.59 & 2.43 \\
\hline Delhi & $\mathrm{Y}=-1.93+0.42 \mathrm{X}$ & 0.42 & 0.58 & 2.38 \\
\hline Varanasi & $Y=-94+0.42 X$ & 0.41 & 0.59 & 2.43 \\
\hline \multicolumn{5}{|l|}{ Vertisols } \\
\hline Sehore & $Y=-2.67+0.39 X$ & 0.39 & 0.61 & 2.56 \\
\hline Raipur & $\mathrm{Y}=-2.84+0.35 \mathrm{X}$ & 0.35 & 0.65 & 2.86 \\
\hline Gulberga & $\mathrm{Y}=-3.42+0.34 \mathrm{X}$ & 0.34 & 0.66 & 2.94 \\
\hline \multicolumn{5}{|l|}{ Alfisols } \\
\hline Hyderabad & $Y=-3.49+0.33 X$ & 0.33 & 0.67 & 3.03 \\
\hline Ranchi & $Y=-3.64+0.34 X$ & 0.34 & 0.66 & 2.94 \\
\hline Bangalore & $\mathrm{Y}=-3.80+0.31 \mathrm{X}$ & 0.31 & 0.69 & 3.23 \\
\hline \multicolumn{5}{|l|}{ Potassium } \\
\hline \multicolumn{5}{|l|}{ Inceptisols } \\
\hline Kanpur & $Y=-1.33+0.59 X$ & 0.59 & 0.41 & 1.69 \\
\hline Faizabad & $\mathrm{Y}=-1.88+0.58 \mathrm{X}$ & 0.58 & 0.42 & 1.72 \\
\hline Delhi & $Y=-7.75+0.75 X$ & 0.75 & 0.25 & 1.33 \\
\hline Varanasi & $\mathrm{Y}=-1.13+0.58 \mathrm{X}$ & 0.58 & 0.42 & 1.72 \\
\hline \multicolumn{5}{|l|}{ Vertisols } \\
\hline Sehore & $Y=-1.45+0.58 X$ & 0.58 & 0.42 & 1.72 \\
\hline Raipur & $\mathrm{Y}=-1.95+0.57 \mathrm{X}$ & 0.57 & 0.43 & 1.75 \\
\hline Gulberga & $Y=-5.79+0.57 X$ & 0.57 & 0.43 & 1.75 \\
\hline \multicolumn{5}{|l|}{ Alfisols } \\
\hline Hyderabad & $\mathrm{Y}=-9.12+0.77 \mathrm{X}$ & 0.77 & 0.23 & 1.29 \\
\hline Ranchi & $Y=-7.04+0.78 X$ & 0.78 & 0.22 & 1.28 \\
\hline Bangalore & $Y=-10.33+0.76 X$ & 0.76 & 0.24 & 1.31 \\
\hline
\end{tabular}




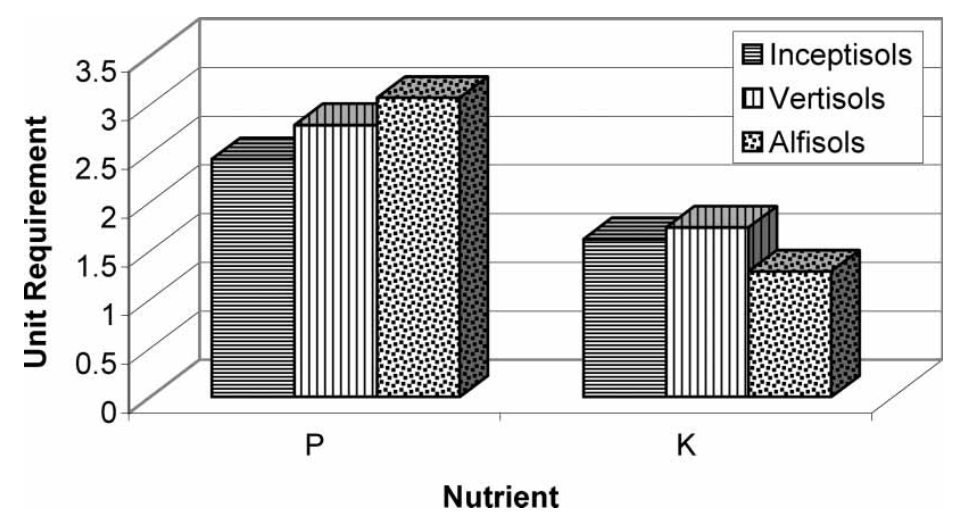

Figure 4. Mean units of fertilizer $\mathrm{P}$ or $\mathrm{K}$ rate required per unit increase in available $\mathrm{P}$ or $\mathrm{K}$ in different soil types.

In the case of $\mathrm{K}$, lower recovery was observed in Vertisols and Inceptisols, whereas Alfisols showed higher recovery. The fixation rates of added fertilizer ranged from 0.25 to 0.42 in Inceptisols, 0.42 to 0.43 in Vertisols, and 0.22 to 0.24 in Alfisols. Based on mean values, Vertisols required the highest units (1.74), followed by Inceptisols (1.62) and Alfisols (1.29) (Figure 4). Rubio and Gil-Sotres (1996) stated that the proportion of clay contributes to $\mathrm{K}$ fixation, and therefore the $\mathrm{K}$ requirement rates increased with increases in fineness of the soil.

These results suggest that considerable variations in $\mathrm{P}$ and $\mathrm{K}$ fixation were found among different soil types as well as within each soil type of pulsegrowing regions. Alfisols showed the highest P-fixation capacity, whereas Vertisols had the highest K-fixation capacity. As most of the pulse-growing soils are medium to high in available $\mathrm{P}$ and low to high in available $\mathrm{K}$ (Srinivasarao et al. 2002), knowledge about fixation/recovery of added P or K may help in formulating the precise fertilizer recommendation for pulse crops.

\section{REFERENCES}

Barrow, N.J. (1979) The description of desorption of phosphate from soil. Journal of Soil Science, 30: 259-270.

Bray, R.H. and Kurtz, L.T. (1945) Determination of total, organic and available forms of phosphorus in soils. Soil Science, 59: 39-45.

Fox, R.L. and Kamprath, E.J. (1970) Phosphate sorption isotherms for evaluating phosphate requirements of soils. Soil Science Society of America Proceedings, 34: 902-907.

Hanway, J.J. and Heidel, H. (1952) Soil analysis methods as used in Iowa State College Soil Testing Laboratory. Iowa Agriculture, 27: 1-13.

Jackson, J.L. (1973) Soil Chemical Analysis; Prentice Hall of India: New Delhi, $38-226$. 
Kanwar, J.S., Goswami, N.N., and Kamath, M.B. (1982) Phosphorus management of Indian soils: Problems and prospects. Fertilizer News, 27: 43-52.

Mallikarjuna, G., Sudhir, K., Srinkant, K., and Srinivasamurthy, C.A. (2003) Phosphorus fixation capacity and its relationship with the soil characteristics in laterite soils of Karnataka. Journal of Indian Society of Soil Science, 51: 23-25.

Mengel, K. (1985) Dynamics and availability of major nutrients in soils. Advances Soil Science, 1: 65-133.

Milap-Chand, N., Randhawa, S., and Vig, A.C. (1995) Phosphorus adsorption characteristics of some benchmark soil of N.W. India and their relationships with soil properties. Journal of Indian Society of Soil Science, 43: 582-586.

Olsen, S.R., Cole, C.V., Watanabe, F.S., and Dean, L.A. (1954) Estimation of available phosphorus by extracting with sodium bi-carbonate. Circular of the United Nations Department of Agriculture; US Government Printing Office: Washington, DC.

Rubio, B. and Gil-Sotres, F. (1996) Determination of K forms in K fertilized soils by electroultrafiltration. Plant and Soil, 180: 303-310.

Sanyal, S.K. and De-Datta, S.K. (1991) Chemistry of phosphorus transformation in soil. Advances in Soil Science, 16: 1-120.

Shaviv, A., Mohsin, M., Pratt, P.F., and Mattigod, S.V. (1985) Potassium fixation characteristics of five southern California soils. Soil Science Society of America Journal, 49: 1105-1109.

Srinivasarao, C., Subba Rao, A., and Rupa, T.R. (2001) Need for inclusion of nonexchangeable potassium in soil test based $\mathrm{K}$ fertilizer recommendations. Fertilizer News, 46: 31-38.

Srinivasarao, C., Ali, M., Ganeshamurthy, A.N., Singh, R.N., and Singh, K.K. (2002) Distribution and availability of nutrients in different soil types of major pulse growing regions of India. Indian Journal of Pulses Research, 15: 49-56.

Srinivasarao, C., Rupa, T.R., Subbarao, A., and Bansal, S.K. (2000) Potassium fixation characteristics of major benchmark soils of India. Journal of Indian Society of Soil Science, 48: 220-228.

Tomar, N.K. and Gautam, K. (1996) Effect of exchangeable sodium percentage on the sorption of orthophosphate and pyrophosphate. Journal of Indian Society of Soil Science, 44: 37-44.

Toor, G.S., Ball, G.S., and Vig, A.C. (1997) Pattern of P availability in different soils as assessed by different adsorption equations. Journal of Indian Society of Soil Science, 45: 719-723.

Verma, O.P. and Verma, G.P. (1970) Potassium fixation in soils of Madhya Pradesh. Bulletin Indian Society of Soil Science, 8: 71-74.

Waugh, D.L. and Fitts, J.W. (1966) Soil test interpretation studies: Laboratory and plotted plant techniques. In International Soil Testing, Series 3; North Carolina State, Agricultural Experiment Station; Raleigh, NC. 
Copyright of Communications in Soil Science \& Plant Analysis is the property of Taylor \& Francis Ltd and its content may not be copied or emailed to multiple sites or posted to a listserv without the copyright holder's express written permission. However, users may print, download, or email articles for individual use. 